\title{
The Rule of Law As a Value in the Sense of Article 2 TEU: What Does It Mean and Imply?
}

\author{
Werner Schroeder
}

\begin{tabular}{|c|c|c|c|}
\hline \multicolumn{4}{|c|}{ Contents } \\
\hline 1 & Dan & gers for the Rule of Law in the Union. & 106 \\
\hline 2 & Orig & ins As a Principle of Union Constitutional Law ... & 107 \\
\hline 3 & No 1 - a & Homogeneity as Regards the Rule of Law in the Union . & 109 \\
\hline \multirow[t]{4}{*}{4} & Nor & native Character of the Union Rule of Law ... & 110 \\
\hline & & Rule of Law As Value and Principle ............. & 110 \\
\hline & & Binding Legal Norm .................. & 112 \\
\hline & & Operational Legal Norm . & 114 \\
\hline \multirow{4}{*}{5} & The & Rule of Law As a Legal Concept. & 116 \\
\hline & 5.1 & Determining the Content of the Rule of Law & 116 \\
\hline & 5.2 & The European Tradition of the Rule of Law ... & 117 \\
\hline & 5.3 & Formal and Material Aspects of the Rule of Law .... & 117 \\
\hline \multirow[t]{3}{*}{6} & The & Rule of Law in the Union's Practice $\ldots \ldots \ldots \ldots \ldots \ldots \ldots \ldots$ & 119 \\
\hline & 6.1 & Rule of Law As Described in the Commission Framework. & 119 \\
\hline & & Rule of Law in the Case Law of the CJEU ................................. & 120 \\
\hline r & Esse & 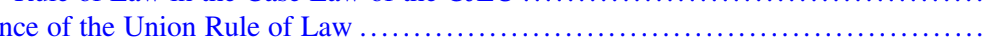 & 122 \\
\hline \multicolumn{3}{|r|}{ References } & 124 \\
\hline
\end{tabular}

\begin{abstract}
The rule of law is a value on which the European Union is founded, and which shall be respected and observed by its Member States. This value is not merely an ethical standard but a binding legal principle that is applicable to legal disputes under Union law. The treaties, however, do not provide a definition of this principle. From a Union law perspective, it is therefore indispensable to determine the rule of law more precisely; not only is it referred to in treaty law (Article 2 TEU), but understood by Union courts as a constitutional meta-principle that informs other constitutional norms and may justify review proceedings and sanctions against Member States. The Commission Framework to strengthen the Rule of Law of 2014 does not suffice to shape a 'Union rule of law'. It relies primarily on the case
\end{abstract}

\footnotetext{
W. Schroeder $(\bowtie)$

Department of European Law and Public International Law, University of Innsbruck, Innsbruck, Austria

e-mail: werner.schroeder@uibk.ac.at
} 
law of the Court of Justice of the European Union. Yet, this judicial concept of the rule of law is somehow restricted as it focuses almost exclusively on the role of the judicial branch in the Union's constitutional system. Common European constitutional traditions, however, show that the core concern of the rule of law is the containment of public authority by institutional arrangements. In view of these traditions and the practice of the Union institutions, including the CJEU, consensus at the Union level might be achieved on the fact that the rule of law comprises not only strictly formal standards, but also material criteria of justice related to the juridical shaping of decision-making processes. These elements of the rule of law are intrinsically linked to fundamental rights and shall ensure that within the scope of Union law any public power is exercised in a non-arbitrary and legitimate way. To this end, the Union rule of law may not only be understood as a formal set of objective norms, but as ensuring the protection of individual rights as well.

\section{Dangers for the Rule of Law in the Union}

According to the first sentence of Article 2 of the Treaty on European Union (TEU), the European Union is founded on values among which figure the respect for human dignity, freedom, democracy, equality, the rule of law and the respect for human rights, including the rights of persons belonging to minorities. The second sentence of this provision assumes that the Member States respect and observe these values. In the last years, however, the political situation in some Member States has made manifest that these values are in part jeopardised to a considerable degree; this notably holds true for the principle of the rule of law ${ }^{1}$ which, as a common principle of the EU Member States, restricts the majority rule in the State through institutions such as separation of powers, independence of the courts and which guarantees the liberty of individuals. ${ }^{2}$ Since the Union draws a great part of its legitimacy from the fact that its organs and Member States respect the rule of law, the indicated dangers for the rule have meanwhile grown into a significant problem for European integration. $^{3}$

It is problematic, however, to operationalise the rule of law in the Union's constitutional system and, in particular, to use it as an argument for sanctioning certain Member States without having clarified its normative character, its meaning and scope. In this contribution the issue of 'content' shall be addressed: What does the principle of the rule of law, as mentioned in Article 2 TEU, actually mean and imply?

\footnotetext{
${ }^{1}$ Scheppele (2015), p. 112.

${ }^{2}$ For the genesis of Art 2 TEU, see Mangiameli (2013), para. 2 note 6.

${ }^{3}$ Kochenov (2013); von Bogdandy and Ioannidis (2014), p. 60; Hillion (2016), pp. 59 et seq.; von Bogdandy et al. (2018), pp. 983 et seq.
} 


\section{Origins As a Principle of Union Constitutional Law}

Already at the beginning of the 1960s, Walter Hallstein coined, in regard to the then European Economic Community (EEC), the concept of a 'community based on law'. ${ }^{4}$ This term has made a remarkable career since then and represents an essential element of Union law doctrine nowadays. ${ }^{5}$ Interestingly, however, Hallstein's remark did not refer to the Member States of the then Community as all being States governed by the rule of law. He did not primarily seek to illustrate that the Community has institutions such as fundamental rights, separation of powers, legal protection and so on, and is therefore endowed with all insignia of a State based on the rule of law. He rather aimed at emphasising that the Community 'solely' disposed of legal power, not of means of coercion. Hence, the Union's power is exclusively based on the respect for the law. ${ }^{6}$ The Union's legal concept for the handling of borderline situations ${ }^{7}$ that involve a threat of the rule of law in and by Member States does not provide for the use of force, but - as it is common in other modern federal systems - relies on cooperation ${ }^{8}$ and consideration. The sanctioning procedure for massive violations of rule of law principles, as enshrined in Article 7 TEU, does little to change this, precisely because it does not allow for the use of force against a Member State.

As is commonly known, the Court of Justice endorsed the notion of a 'community based on law' in its famous Les Verts v. Parliament-Ruling in 1986, linking it to the constitutional character of the Treaties. According to the Court, the then EEC is 'a Community based on the rule of law, inasmuch as neither its Member States nor its institutions can avoid a review of the question whether the measures adopted by them are in conformity with the basic constitutional charter, the Treaty'. ${ }^{9}$ Methodologically, this jurisprudence draws on the fact that the rule of law stems from a common European heritage. It can be conceived of as an element of the common constitutional traditions of the Member States and as an element of the European Convention for the Protection of Human Rights and, therefore, as a general principle of Union Constitutional law. ${ }^{10}$ The Court of Justice made the topos of the rule of law

\footnotetext{
${ }^{4}$ Hallstein (1979), p. 109. See also Fuß (1968), pp. 16 et seq.

${ }^{5}$ Critically von Bogdandy (2017), p. 487.

${ }^{6}$ Hallstein (1969), p. 33.

${ }^{7}$ For the state of emergency as a test case of jurisdiction, see Schmitt (1985), p. 11. Critically with regard to the application of Schmitt's theory to the Union system, see Pernice (1995), pp. 109 et seq.; Schroeder (2002), p. 220.

${ }^{8}$ Scharpf (1985), pp. 323 et seq.

${ }^{9}$ CJEU, Case C-294/83 Les Verts v. Parliament, ECLI:EU:C:1986:166, para. 23; Joined Cases C-402/05 P and C-415/05 P Kadi and Al Barakaat International Foundation v. Council and Commission, ECLI:EU:C:2008:461, para. 281. But see CJEU, Case C-362/14 Schrems v. Data Protection Commissioner, ECLI:EU:C:2015:650, para. 60: the European Union is a 'union based on the rule of law'.

${ }^{10}$ von Bogdandy (2009), pp. 23, 28 et seq.; Pech (2010), pp. 361 et seq., 367. On the general principle see Tridimas (2013).
} 
part and parcel of its own constitutionalisation strategy. ${ }^{11}$ It perfectly lends itself to support the proposition that the Union is not an intergovernmental organisation as the others, but a public authority sui generis endowed with a supranational constitution. ${ }^{12}$ The Court of Justice also applies such 'constitutional' and 'rule of law' terminology to the effect of securing the substantial legitimacy of the law of the Union, particularly by underscoring that the rule of law constitutes an element of the Union's particular identity on the international plane. ${ }^{13}$

It has, however, taken several decades for the rule of law to acquire the status of and establish itself as a principle pertaining to the constitutional law profile of the Union (Article 2, second sentence and Article 7 TEU), i.e. to be understood as a 'constitutional principle'. ${ }^{14}$ This is understandable, given the fact that the objectives and means of operation originally agreed upon by the Member States of the Community were primarily of an economic and social-policy character, with the 'Common Market' and 'market freedoms' forming the heart of this economic order. Therefore, the Treaties of Rome did not contain, with the exception of legal protection, any elements testifying an explicit rule of law terminology. ${ }^{15}$

With the advent of the interpretation of the Treaties as a constitution which organises and legitimises supranational public authority not only in economic, but also in highly political fields, the Member States became increasingly interested in giving an explicit status to 'constitutional principles' governing the Union's public authority. The rule of law principle, as one of these constitutional principles, is first mentioned in a Union law context in the Conclusions of the European Council of Copenhagen in 1993 committing the candidate countries for EU membership to 'stability of institutions guaranteeing democracy, the rule of law, human rights, respect for and protection of minorities'. ${ }^{16}$ The Amsterdam Treaty of 1997 adopts this approach inasmuch as in Article 6 paragraph 1 TEU it states that the Union is founded on the principles of liberty, democracy, the respect for human rights and fundamental freedoms; these principles are common to all Member States. In Article I-2 of the 2004 Treaty establishing a Constitution for Europe which has not entered into force, these principles were re-baptised as 'values'. This very term, by the way, is also used by the identical provision of Article 2 TEU.

\footnotetext{
${ }^{11}$ See Weiler (1981), p. 274; Mancini (1989), pp. 595 et seq.; Lenaerts (1990), pp. 205 et seq. See also Fuß (1968), pp. 16 et seq.; Hallstein (1969), pp. 41, 48 et seq.

${ }^{12}$ CJEU, Opinion 1/91 EEA I, ECLI:EU:C:1991:490, para. 108; Opinion 2/13 Accession of the EU to the ECHR II, ECLI:EU:C:2014:2454, paras. 156 et seq., 163 et seq.

${ }^{13}$ In contrast to the UN system, see CJEU, Kadi, supra note 9, paras. 281 et seq. See further Hilf and Schorkopf (2015), paras. 12-54.

${ }^{14}$ See von Bogdandy (2009), pp. 13, 22.

${ }^{15}$ Calliess (2011), para. 1. On the impact of the deepening of European integration for the meaning of the rule of law see Lenaerts (2017a), p. 640.

${ }^{16}(1993) 26$ (6) EC Bull, para. I.13.
} 


\section{No Homogeneity as Regards the Rule of Law in the Union}

Article 2 TEU is sometimes referred to as a 'homogeneity clause'. It is derived from Article 2, first and second sentence TEU as well as from Article 7 TEU that a similar rule of law standard applies both vertically between the Union level and the Member States' level and horizontally among the Member States themselves. Every exercise of public authority, irrespective of whether it has its origin on the Union or national level, is subject to a set of legal limitations and shall be assessed according to this standard. $^{17}$

Such claims for congruence of constitutional principles in federal systems are often based on federal ideas or models. ${ }^{18}$ When applied to the law of the Union, they imply the existence of a supremacy of the Union vis-à-vis its Member States and suggest supervisory powers in the relationship between the both. But can a claim for constitutional homogeneity and for similar rule of law standards on Union and national level be sustained under these conditions in the first place? Such a claim is in need of critical reflection. First of all, it is problematic to reconstruct the Union's constitution in the light of federal state models since the institutional situation of the Union follows its own rules. ${ }^{19}$ Even though the Union exercises and organises public authority, ${ }^{20}$ only limited conclusions for the understanding of the Union's constitution can be drawn from theories that take national federal systems as their point of reference. In view of the different nature of the Union as a community of integration, its constitutional structures and principles differ from those of the Member States. ${ }^{21}$ The claim for constitutional homogeneity between Union and Member States must thus be rejected. ${ }^{22}$

Furthermore, it is difficult to assume that there exists a form of rule of law homogeneity in the relationship among the Member States (horizontally). No Union law fiction is available in this regard since, concerning essential constitutional

\footnotetext{
${ }^{17}$ Hilf and Schorkopf (2015), paras. 9 et seq.; Pech (2010), p. 364; Mangiameli (2013), paras. 42 et seq.; von Bogdandy et al. (2012), pp. 509 et seq.

${ }^{18}$ For a homogeneity requirement with respect to federalism and the principle of democracy, Schmitt (2008), p. 388. With respect to positive constitutional law see Art. 28 para. 1 German Basic Law, which is calling for constitutional homogeneity between the German Basic Law and the federal states. The German Constitutional Court handles the claim strictly, see BVerfG, $1 \mathrm{BvL}$ 30/88, Rundfunkentscheidung, Judgment of 22 February 1994, paras. 84-88. See also Art. 99 para. $1 \mathrm{~B}-\mathrm{VG}$, which states that the state constitutions in Austria may not contradict the federal constitution. This does also apply for the principle of the rule of law.

${ }^{19}$ See CJEU, Case C-359/92 Germany v. Council, ECLI:EU:C:1994:306, para. 38. Against constitutional analogies, see also ECtHR [GC], Matthews v. United Kingdom, Judgment of 18 February 1999, Application No. 24833/94, para. 48.

${ }^{20} \mathrm{CJEU}$, Opinion 1/78 International Agreement on Natural Rubber, ECLI:EU:C:1979:224, para. 7.

${ }^{21}$ BVerfG, Judgment of 31 May 1995, 2 BvR 635/95. See previously BVerfG, 1 BvR 1474/92, Maastricht, Judgment of 17 August 993, para. 182; BVerfG, 2 BvE 2/08, Lissabon, Judgment of 30 June 2009, para. 370.

${ }^{22}$ But see von Bogdandy et al. (2012), p. 489.
} 
principles such as the content of human dignity, there is no respective 'common conception' of the Member States, as the CJEU has acknowledged. ${ }^{23}$ Also with respect to the other elements of the rule of law such as legal protection, separation of powers and so on, as regards the details a common conception of the Member States cannot be found. ${ }^{24}$

The claim for the rule of law should therefore not be understood as a claim for homogeneity. This would do justice neither to the European constitutional reality nor to the Treaties. Article 4 paragraph 2 TEU acknowledges that the 'national identity' of the Member States, which the Union shall respect, is based on their 'fundamental structures, political and constitutional'. Thus, it is the law of the Union itself recognising that, in spite of the common constitutional values of Article 2 TEU, there exist differences between the Union's constitution and the constitutions of the Member States. Individual national approaches as to the legal classification of the rule of law confirm such an understanding. ${ }^{25}$ In areas where Union law may not ensure a uniform level of legal protection, it leaves room for 'rule of law diversity', provided that the 'primacy, unity and effectiveness of EU law are not thereby compromised'. ${ }^{26}$ The idea that Article 2 TEU orders and supervises a federal statetype constitutional homogeneity-vertically as well as horizontally-is not compatible with such a model of constitutional pluralism ${ }^{27}$ as it is after all laid down explicitly in the Treaty.

The claim for the rule of law of the Union and the Member States does therefore not seek the existence of uniform principles and rules, but solely the observance of a European minimum standard in terms of the rule of law. ${ }^{28}$ To define this minimum standard, however, is not an easy task (see Sect. 5 below).

\section{Normative Character of the Union Rule of Law}

\subsection{Rule of Law As Value and Principle}

It has already been mentioned that the rule of law was first referred to as a 'principle' in the Amsterdam Treaty and has only been modified into a 'value' with the Lisbon

\footnotetext{
${ }^{23}$ CJEU, Case C-36/02 Omega, ECLI:EU:C:2004:614, para. 37.

${ }^{24}$ Regarding the difference of the rule of law in common law and continental legal systems, see Dicey (1961), pp. 189 et seq., 267 et seq.; Konstantinides (2017), pp. 30 et seq., 39; Krygier (2012), p. 233; Classen (2013), pp. 56 et seq.

${ }^{25}$ On the constitutional identity control, see BVerfG, Lissabon, supra note 21, para. 343, according to which the 'inviolable core content of the constitutional identity of the Basic Law' has to be respected within the framework of the Union.

${ }^{26}$ CJEU, Case C-399/11 Melloni, EU:C:2013:107, para. 60.

${ }^{27}$ On constitutional pluralism in the EU, see MacCormick (1995), p. 259; Baquero Cruz (2008), p. 389.

${ }^{28}$ Lenaerts (2017a), p. 640.
} 
Treaty. Although terminology issues should not be overrated in Union law, the question arises what normative consequences this renaming may have. Most scholars take the position that nothing has changed from a legal point of view. They continue to use the term 'principles' as it represents a common category of legal hermeneutics. ${ }^{29}$ They interpret the 'linguistic turn' as merely indicating the theoretical uncertainties of the law of the Union in the dealing with constitutional principles. In addition, they refer to the case law of the CJEU, Article 21 TEU and the Preamble of the FRC which, in the context of the rule of law and fundamental rights, continue speaking of 'constitutional principles' ${ }^{30}$ and 'principles'. 31

It is indeed problematic to use the term 'values' in Article 2 TEU because it is a meta-legal term. Values shall, beyond the realm of legal norms, guide the individual in decision-making situations to ethically 'right' conduct. They articulate general considerations on the basis of which one state of affairs is declared preferable in relation to another state of affairs. ${ }^{32}$ As moral strategies, values only function on the basis of a consensus on their respective set and content which cannot, however, be assumed and realised at any given time.

However, the distinction between principles and values can be normatively reconstructed on the basis of Union law itself. First of all, values, insofar as they are laid down in black-letter legal texts, such as Article 2 TEU, refer to doctrinal principles which shall guide decision-makers in the Union in their structuring of the legal order. In this context, principles are understood in a pragmatic manner. ${ }^{33}$ They are understood as legal norms which do not state specific rights or duties, but which are of a general nature and are in need of being concretised by the legislative, the executive and the judiciary. They can be made operable in the Union legal system by means of adopting more specific legal rules, in particular, by the courts that-by drawing on principles, values, interests and goods which, thus, become an element of a balancing decision-identify them as legally relevant. In so doing, the CJEU has, for instance, derived the principle of legal certainty from the rule of law principle. ${ }^{34}$ In such a case, a principle can even turn into a self-standing standard of legality.

Secondly, in the Union legal system, values as being ethical, supra-positive norms have an orientation and ordering function. They are therefore of an identitybuilding and legitimacy-creating character. ${ }^{35}$ This is also the function of the rule of

\footnotetext{
${ }^{29}$ See von Bogdandy (2009), pp. 22 et seq.; Pech (2010), pp. 366 et seq.; Hilf and Schorkopf (2015), para. 21.

${ }^{30}$ CJEU, Kadi, supra note 9, paras. 281, 285; Case C-355/04 Segi, ECLI:EU:C:2007:116, para. 51.

${ }^{31} \mathrm{CJEU}$, Accession of the EU to the ECHR II, supra note 12, para. 167.

${ }^{32}$ Luhmann (1987), p. 433.

${ }^{33}$ On different interpretations of the function of principles in the law of the Union, see von Bogdandy (2009), p. 20; Bengoetxea (1993), pp. 183 et seq.; Schroeder (2002), pp. 262 et seq.

${ }^{34}$ See CJEU, Case C-234/04 Kapferer v. Schlank \& Schick GmbH, ECLI:EU:C:2006:178, paras. 20 et seq.

${ }^{35}$ Calliess (2004), p. 1034.
} 
law and of the other values mentioned in Article 2 TEU which shall endow the Union with a particular identity, ${ }^{36}$ especially on the international level (see Article 3 paragraphs 1 and 5 TEU, Article 8 TEU in Article 21 paragraph 2, Article 32 and Article 42 paragraph $5 \mathrm{TEU}$ ), but also vis-à-vis the Union citizens inasmuch as they can form the basis of a common political conscience. ${ }^{37}$ The value of the rule of law, in particular, is that of a reference standard for the common self-assurance of the Union and its Member States. ${ }^{38}$

In view of the foregoing, the third point is that values have therefore a legal and ethical double-nature. Legal norms concretise values and transform them from the societal system into the legal system. This double-nature of the rule of law as a value of the Union and a principle of Union law also becomes manifest in the structure of Article 2 TEU. In Article 2, second sentence TEU values such as pluralism, tolerance, solidarity are characterised as contents of the European societal model that have no legal character. The Union is not 'founded' on these values but presupposes them as societal values. This distinction is taken further in the provision on the sanctioning procedure in Article 7 paragraph 1 TEU which solely refers to the 'legally relevant values' in the meaning of Article 2 paragraph 1 TEU. It has also left terminological traces in the CJEU's case law. In the context of human dignity, the Court of Justice, on the one hand, speaks of it as a 'fundamental value' laid down in the national constitutions, but on the other hand also as a 'general principle of [Union] law' ${ }^{39}$ And in its opinion on the accession of the Union to the ECHR, the Court of Justice declares that the legal structure of the Union is based on the fundamental premise that each Member State shares with all the other Member States [...] a set of common values on which the EU is founded, as stated in Article 2 TEU. $^{40}$

\subsection{Binding Legal Norm}

If a norm is referred to as a value, this means to shift it to a political or ethical level. In terms of legal doctrine, this creates problems. It notably gives rise to the question of how the values which are laid down in the Union's constitution should be interpreted and applied. Are they subject to judicial control or a standard for such a control?

\footnotetext{
${ }^{36}$ See Commission 'Communication on Article 7 of the Treaty on European Union: Respect for and promotion of the values on which the Union is based' COM (2003) 606 final, 3.

${ }^{37}$ von Bogdandy (2009), p. 14.

${ }^{38}$ Lenaerts (2017a), p. 640.

${ }^{39} \mathrm{CJEU}$, Omega, supra note 23, paras. 23, 32, 34.

${ }^{40} \mathrm{CJEU}$, Accession of the EU to the ECHR II, supra note 12, para. 168.
} 
First of all, one must refer to the fact that the rule of law is enshrined in Article

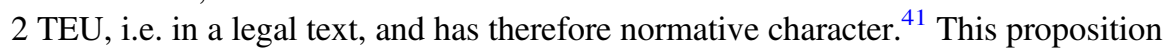
is emphasised by the wording and system of the Treaty, namely by pointing out that the rule of law is 'common' to the Member States and that the Union is 'founded' on it, amongst others (Article 2 TEU). The normative character of the rule of law also becomes manifest in Article 3 paragraph 1 TEU which makes it the Union's primary goal to promote its values, as well as in Article 13 paragraph 1 TEU which makes the promotion of values the reference point of the 'institutional framework' of the Union. Both the Union's institutions and the Member States are legally bound by the treaty objectives of the Union, as also follows from Article 4 paragraph 3 TEU. The normative character of the rule of law is further confirmed by the references in the sanctioning procedure pursuant to Article $7 \mathrm{TEU}^{42}$ and the accession procedure pursuant to Article 49 TEU. ${ }^{43}$ In these cases, specific legal consequences are tied to the respect for and the promotion of the rule of law. This presupposes that the rule of law itself is of legally binding nature.

Moreover, Article 2 TEU only constitutes the black-letter law manifestation of principles which have already been developed by the CJEU in the 1980s as unwritten general principles of law. ${ }^{44}$ Against this background, the reference in Article 2 TEU to such principles and their denomination as values is of solely declaratory nature. They do not change their already existing normative character. Their codification is above all relevant as a reference point for the sanctioning procedure against the Member States pursuant to Article 7 TEU as well as for reasons of legal certainty.

In addition, the rule of law has, together with the other values referred to in Article 2 TEU, a programmatic function. Their respect by the Member States is evoked in Article 2, second sentence TEU, and for the Union itself this provision serves as characterisation of the classical structural features of the liberal constitutional model. ${ }^{45}$ Due to the systematic position at the beginning of the Treaties, its profound character, its open wording as well as its significance similar to goal and value clauses in the constitutions of some Member States, Article 2 TEU constitutes the fundament of a membership in the Union. ${ }^{46}$ Besides, the promotion of the rule of law is, according to Article 3 paragraph 1 TEU, one of the overarching objectives of the Union and its institutional framework (Article 13 paragraph 1 TEU). The realisation of the principle of the rule of law, therefore, pertains to the decision-making programme for the Union's institutions which determines the handling of their

\footnotetext{
${ }^{41}$ This can be illustrated in the light of the CJEU's case law on Articles 2 and 3 EEC Treaty, which were regarded as legally binding norms, see CJEU, Case C-126/86 Giménez Zaera, ECLI:EU: C:1987:395, para. 14; Case C-339/89 Alsthom Atlantique, ECLI:EU:C:1991:28, paras. 8 et seq.

${ }^{42}$ See Commission 'Reasoned proposal under Article 7 para. 1 TEU regarding the rule of law in Poland' COM (2017) 835 final, para. 1.

${ }^{43}$ Ohler (2015), para. 15; Cremona (2005), p. 3.

${ }^{44}$ CJEU, Case C-138/79 Roquette Frères, ECLI:EU:C:1980:249, para. 33; Les Verts, supra note 9, paras. 23 et seq. See also Lenaerts (2017a), p. 640.

${ }^{45}$ Hilf and Schorkopf (2015), para. 9; von Bogdandy (2009), p. 22.

${ }^{46}$ Pech (2010), pp. 361 et seq.; Calliess (2004), p. 1036.
} 
discretionary powers ${ }^{47}$ and constitutes a guideline for the interpretation of Union law provisions. ${ }^{48}$ By virtue of Article 4 paragraph 3 TEU, this objective entails legal effect vis-à-vis the Member States which must refrain from any measures that could jeopardise the attainment of the Union's objectives and shall, vice versa, do everything to facilitate the achievement of the Union's tasks. ${ }^{49}$

\subsection{Operational Legal Norm}

Although it is now undisputed that the rule of law is a legally binding norm, the question arises whether it is also applicable in a legal dispute. The vagueness of the concept of the rule of law-more on this later-raises the question of whether this norm has any self-standing value in legal procedures. ${ }^{50}$

In fact, the Court of Justice has emphasized the normative character of the rule of law principle very early by deriving concrete legal rules from this principle, for example, the duty of the Union to provide legal protection mechanisms. ${ }^{51}$ Later, the Court has operationalised the rule of law. Specifically, by referring to the rule of law it called on the Member States to ensure judicial independence and the full judicial protection of the rights of individuals. ${ }^{52}$ By now, the rule of law is well established as an operational principle and as a basis for legally assessing the Member States. ${ }^{53}$

The premise that each Member State respects the rule of law, as stated in Article 2 TEU, also entails legal consequences as far as it forms the basis of the principle of mutual recognition. The legal concept of mutual recognition, which is based upon mutual trust among the Member States that Union law will be respected, ${ }^{54}$ draws on the idea that in areas which have not been fully harmonised by the Union, the authorities of a Member State have to accept the legal acts of another Member State in regard to certain factual circumstances as binding, thus treating them as if they had been decided upon by the Member State's own legal order. ${ }^{55}$ Important fields of application of this principle are the Union citizenship, where the Member States must recognise the grant of citizenship by another Member State,${ }^{56}$ or legal acts in

\footnotetext{
${ }^{47}$ CJEU, Case C-14/68 Wilhelm and Others v. Bundeskartellamt, ECLI:EU:C:1969:4, para. 5.

${ }^{48}$ See Case C-6/72 Europemballage Corporation and Continental Can Company v. Commission, ECLI:EU:C:1973:22, para 24; EEA I, supra note 12, para. 18.

${ }^{49} \mathrm{CJEU}$, Wilhelm and Others v. Bundeskartellamt, supra note 47 , paras. 6 et seq.

${ }^{50}$ Kochenov (2015), p. 88.

${ }^{51}$ CJEU, Les Verts, supra note 9, para. 23.

${ }^{52}$ CJEU, Case C-619/18, Commission v. Poland, ECLI:EU:C:2018:910, para. 21; Case C-216/18 PPU, Minister for Justice and Equality (LM), ECLI:EU:C:2018:586, paras. 48 et seq.

${ }^{53}$ von Bogdandy et al. (2018), p. 986.

${ }^{54}$ CJEU, EEA I, supra note 12, para. 168.

${ }^{55}$ Möstl (2010), p. 405.

${ }^{56}$ CJEU, Case C-200/02 Zhu and Chen, ECLI:EU:C:2004:639, para. 37.
} 
the Area of Freedom, Security and Justice (AFSJ) such as the European Arrest Warrant on the basis of Framework Decision 2002/584/JHA. ${ }^{57}$

It becomes clearer and clearer, however, that in some Member States the legislative, administrative and judicial procedures do not satisfy the rule of law minimum standards which are presupposed by the principle of mutual recognition. In such a case, there is no basis in Union law for the recognition of such procedures and decisions by other Member States ${ }^{58}$ since 'mutual recognition' must be performed in conformity with primary law, i.e. in conformity with Article 2 TEU. Hence, the CJEU has expressly obliged the Member States, in particular, national courts and administrative bodies to suspend their legal cooperation with such Member States that massively violated rule of law minimum standards. ${ }^{59}$ More recent legal acts demonstrate that the Union legislator has become aware of this problem, too. For instance, according to Article 11 paragraph 1 lit f) of the Directive 2014/41/EU regarding the European Investigation Order in criminal matters ${ }^{60}$ the recognition or execution of a European Investigation Order on gathering evidence for criminal proceedings issued by the authorities of one Member State may be rejected by the authorities of other Member States where there are substantial grounds to believe this could be incompatible with Article 6 TEU and the FRC. Besides, Article 3 paragraph 2 sub-paragraph 2 of the Regulation (EU) 604/2013 ${ }^{61}$ (Dublin III Regulation) obliges the Member States, when determining which Member State is responsible for the examining of an application for international protection, to also check whether 'there are substantial grounds for believing that there are systemic flaws in the asylum procedure and in the reception conditions for applicants in [another] Member State, resulting in a risk of inhuman or degrading treatment'. In such case, the determining Member State must not transfer the applicants in that other Member State. ${ }^{62}$

\footnotetext{
${ }^{57}$ See CJEU, Case C-303/05 Advocaten voor de Wereld, ECLI:EU:C:2007:261, paras. 28 et seq.

${ }^{58}$ See CJEU, Case C-135/08 Rottmann, ECLI:EU:C:2010:104, paras. 48 et seq. for the limits of recognition of granting citizenship by a Member State by the others in arbitrary decisions.

${ }^{59}$ See CJEU, Joined Cases C-411/10 and C-493/10 N.S. and Others, ECLI:EU:C:2011:865, para. 86, regarding Council Regulation (EC) 343/2003 establishing criteria and mechanisms for determining the Member State responsible for examining an asylum application lodged in one of the Member States by a third-country nation (Dublin II Regulation) (2003) OJ L 50/1. With regard to the European Arrest Warrant, see CJEU, Joined Cases C-404/15 and C-659/15 PPU Aranyosi and Căldăraru, ECLI: EU:C:2016:198, paras. 77 et seq.; Case C-452/16 PPU Poltorak, ECLI:EU: C:2016:858, paras. 44 et seq.; LM, supra note 52, para. 59. See further Lenaerts (2017b), pp. 810 et seq.

${ }^{60}$ (2014) OJ L130/1.

${ }^{61}$ Regulation (EU) 604/2013 of the European Parliament and of the Council establishing the criteria and mechanisms for determining the Member State responsible for examining an application for international protection lodged in one of the Member States by a third-country national or a stateless person (Dublin III Regulation) (2013) OJ L 180/31.

${ }^{62}$ See CJEU, Case C-578/16 PPU C.K., ECLI:EU:C:2017:127, paras. 92 et seq.
} 
These examples demonstrate that the systematic disregard by a Member State of rule of law minimum standards in the scope of application of EU law also can have directs effects on the legal cooperation with other Member States. ${ }^{63}$

\section{The Rule of Law As a Legal Concept}

It is problematic, however, to operationalise the rule of law without having clarified its content before.

\subsection{Determining the Content of the Rule of Law}

In fact, it is often questioned whether the rule of law, despite its importance being undisputed, is able to perform a valuable function for the Union's legal order as it is too vague and undetermined. ${ }^{64}$ Ambiguities as to the content of the Union rule of law can be explained, first of all, by the fact that the Treaties do not contain explicit statements on rule of law issues. To be sure, Articles 7 and 49 TEU refer to the rule of law via Article 2 TEU. Yet, the Treaties do not define what is to be understood by this concept.

The Commission and the courts when enforcing the rule of law vis-à-vis a certain Member State, however, cannot simply refer to Article 2 TEU and content themselves to an 'I know it when I see it'-approach. ${ }^{65}$ A concretisation of the rule of law beyond the mere reference in Article 2 TEU is, however, needed from the point of view of the rule of law itself. The principle of legal determinateness requires that legal provisions which impose a certain code of conduct on legal subjects are sufficiently specific, so that the persons affected by them can align their conduct with these provisions. ${ }^{66}$ In addition, the policies adopted by some Member States have shown that a lack of consensus on the content of the Union rule of law might be understood as an invitation to test the limits of Article 2 and 7 TEU.

\footnotetext{
${ }^{63}$ von Bogdandy et al. (2018), pp. 992 et seq.

${ }^{64}$ Kochenov (2015), p. 79; Claes and Bonelli (2016), pp. 267 et seq.; Barnett (2018), p. 24.

${ }^{65}$ This famous phrase on the difficulties of legal decision-making appears in U.S. Supreme Court, Jacobellis v. Ohio, 378 U.S. 184 (1964) p. 197 (Stewart, J, concurring).

${ }^{66} \mathrm{CJEU}$, Joined cases 212 to 217/80 Amministrazione delle finanze dello Stato v. Meridionale Industria Salumi and Others, ECLI:EU:C:1981:270, para. 10; Barnett (2018), p. 26.
} 


\subsection{The European Tradition of the Rule of Law}

There might be a number of reasons why the conceptions as to the content and significance of the rule of law in Europe are unclear, even though the preamble of the TEU refers to the rule of law as a 'universal value'. ${ }^{67}$ One of these reasons is certainly that the concept of the rule of law has a more limited European tradition than, for example, the concept of democracy which is meanwhile extensively described in Articles 9 et seq. TEU.

To be sure, the concept of rule of law can be long traced back, at least in the English history of law. The concepts of rule of law in the UK, of 'Rechtsstaatlichkeit' in Germany and of 'État de droit' in France have, however, developed a particular impact only after the nineteenth century and flourished in the era of European constitutionalism. ${ }^{68}$ Even more, most EU Member States' constitutions are familiar with the concept of the rule of law only since the 1970s. Ultimately, there is a considerable range of legal concepts in Europe which are gathered under the notion of the rule of law.

\subsection{Formal and Material Aspects of the Rule of Law}

Regardless of different approaches and rule of law traditions most would agree that a basic meaning of the rule of law comes down to the idea that all public power must act within certain constraints by law, i.e. that it is bound by legal norms which are outside of its control. ${ }^{69}$ The rule of law is a legal principle organising the relationship between a community and its governing institutions, reducing the discretion of public power by subjecting it to means of effective legal and judicial control. ${ }^{70}$

Sometimes doubts are expressed concerning the usefulness of this broad definition. ${ }^{71}$ It reveals that the rule of law does not constitute a straightforward concept, but rather an aggregate notion for a set of subprinciples which are themselves in need of concretisation depending on the respective context. ${ }^{72}$ It is correct that constitutional law problems are primarily to be solved on the basis of constitutional subprinciples that form part of the meta-concept of the rule of law but are closer to the problem, for example, principles such as legal certainty or separation of powers; the concept of rule of law should be drawn upon only subsidiarily. At the same time,

\footnotetext{
${ }^{67}$ Cruz Villalón (2007), para. 60.

${ }^{68}$ For a comparative analysis, see Loughlin (2010), pp. 312 et seq., especially 314 et seq.; Heuschling (2002), pp. 384 et seq.; Holterhus (2017), pp. 453 et seq.

${ }^{69}$ Kochenov (2015), p. 81; Crabit and Bael (2016), p. 198.

${ }^{70}$ Holterhus (2017), p. 432; Konstantinides (2017), pp. 29 et seq.; Sobotta (1997), pp. 21 et seq.

${ }^{71}$ See Kunig (1986), pp. 89 et seq., 457 et seq.

${ }^{72}$ Waldron (2008), p. 3; Holterhus (2017), p. 432. See the case law of the German Constitutional Court, e.g. BVerfG, 2 BvL 25/81, Judgment of 22 November 1983 (BVerfGE 65, 283, 290).
} 
the rule of law is far from being a mere ideological formula without any normative self-reliance. It has an autonomous role where the challenge is to link these various elements in systematic fashion in order to thereby obtain functional insights. ${ }^{73}$

Against this background, it may not come as a surprise that there is a discourse in Europe on which subprinciples may be attributed to the rule of law and form part of it. At the heart of the struggle for conceptualising the rule of law lies the choice between a formal ('thin') or on a material ('thick') concept. ${ }^{74}$ Behind this discourse lies the question of whether the rule of law principle is identical to claims regarding 'process and form' or whether it also contains demands concerning the content of legal norms in terms of fairness. Formal interpretations of the rule of law as mere obligation to respect the law were for a long time not only common in the UK. ${ }^{75}$ The principle of legality and other aspects associated with formal rule of law qualities like the hierarchy of norms also constitute the core elements of the formal 'Rechtsstaatlichkeit' in Germany, Austria and France. ${ }^{76}$ In fact, representatives of a 'negative' or 'thin' concept of the rule of law caution even today against overburdening the concept with diverse social objectives, so that it does not become devoid of content and practically irrelevant. They assert that the core of the rule of law rather consists of a set of requirements such as that the legal norms of a given legal order should be general, public, prospective and certain. ${ }^{77}$

There is some truth to this warning, but it is also true that according to most constitutional provisions in Europe, legal norms must satisfy elementary requirements of justice in regard to an obligation of fairness and prohibition of arbitrariness. This claim for a just creation, application and interpretation of legal norms is secured by virtue of binding the legislator to the constitution and material constitutional principles such as fairness, equality and certainty of law. ${ }^{78}$ This conception of the rule of law which is based on a combination of both formal and material aspects has become the most accepted one in many Member States. ${ }^{79}$ This approach has also found favour on the Union level as will be shown below.

\footnotetext{
${ }^{73}$ Schmidt-Aßmann (2004), § 26 paras. 8 et seq. See also BVerfG, 2 BvR 215/81, Judgment of 26 March 1981 (BVerfGE 57, 250, 276) where the principle of the rule of law 'selbst' (itself) is used as a systematically relevant anchor for requirements of procedures.

${ }^{74}$ Magen (2016), p. 1052; Wennerström (2007), pp. 76 et seq.

${ }^{75}$ See especially Dicey (1961), p. 188. Critically, Craig (1997), pp. 470 et seq.; Krygier (2012), pp. 236 et seq.

${ }^{76}$ Classen (2013), pp. 63 et seq.; Loughlin (2010), pp. 315 et seq.

${ }^{77}$ See e.g. Raz (1977), pp. 210 et seq.

${ }^{78}$ See e.g. Dworkin (1985), pp. 335 et seq. Regarding Germany, see von Simson (1982), p. 109.

${ }^{79}$ Bingham (2010), p. 37.
} 


\section{The Rule of Law in the Union's Practice}

\subsection{Rule of Law As Described in the Commission Framework}

The Commission has sought such clarification in its Communication of 11 March 2014 on a 'New framework to strengthen the rule of law' ${ }^{80}$ The text represents some principles meant to be common to the constitutional traditions in Europe. It relies, however, on the case law of the CJEU when identifying the elements of the rule of law. ${ }^{81}$ The CJEU judgments cited in the Communication refer to the principles of legality, legal certainty, effective legal protection as well as prohibition of arbitrariness, but only in regard to the conduct of the Union's institutions and mostly in the field of European competition law. These judgements of the Court of Justice do, however, not deal with the legal situation in the Member States, i.e. whether the conduct of the national powers meets the rule of law standard of the Union.

This does not suffice to give shape to a Union rule of law in the meaning of Article 2 TEU. The reference of the framework to the CJEU's jurisprudence may serve as an indicator when determining the rule of law, but it should be taken into account that the exercise of public authority by Union institutions and national authorities cannot be equally treated in legal terms ${ }^{82}$ and that the national constitutional traditions regarding the rule of law in Europe may differ from the concept pursued by the CJEU. Moreover, the framework itself has the character of a checklist that has been created in an inductive way. Like other rule of law checklists, it does not claim to be exhaustive nor of absolute character. ${ }^{83}$

The added value of the new rule of law framework of the Commission particularly lies in the fact that on the basis of a dialogue between the Commission and Member States, the Member States' obligations deriving from the rule of law can be specified. Accordingly, the biggest shortcoming of the Union rule of law, i.e. the indeterminacy as regards its content, can be overcome. The Commission has sought to strengthen the normative relevance of its rule of law definition by reiterating the framework in legal documents relating to the rule of law situation in certain Member States. ${ }^{84}$ In addition, it has relied on the framework's rule of law interpretation in its proposal for a regulation on the protection of the Union's budget in case of generalised deficiencies as regards the rule of law in the Member States. However,

\footnotetext{
${ }^{80}$ Commission 'Communication from the Commission to the European Parliament and the Council: a new EU Framework to strengthen the Rule of Law' COM (2014)158 final, 4 and Annex 1; see Crabit and Bael (2016), p. 197; von Bogdandy et al. (2018), pp. 985 et seq.

${ }^{81}$ See Lenaerts (2017a), p. 641.

${ }^{82}$ See CJEU, Germany v. Council, supra note 19, para 38. Against constitutional analogies also ECtHR, Matthews v. United Kingdom, supra note 19, para. 48.

${ }^{83}$ See Fuchs (2018), pp. 239, 243 with regard to the 'Rule of Law Checklist' of the Venice Commission for Democracy through Law (Study No. 711/2013, CDL-AD(2016)007 Strasbourg 18 March 2016).

${ }^{84}$ See COM (2017) 835 final, supra note 42, para. 1 and other documents relating to the situation in Poland (SWD/2018/219 final).
} 
these measures have contributed little to the establishment of a specific Union rule of law definition because the Commission's definition merely consists of a list of legal subprinciples. $^{85}$

\subsection{Rule of Law in the Case Law of the CJEU}

It has already been outlined that the Court of Justice uses a rule of law terminology reminiscent of national constitutional law and has located the source of the rule of law in the general legal principles of Union law. However, questions arise as to which substantive changes are associated with the conceptual extension and application of the rule of law to the Union level. What are the attributes of a 'Union based on the rule of law'? ${ }^{86}$

The case law of the Court of Justice is based on a twofold concept reflecting formal as well as substantive aspects of the rule of law. The formal binding of the public authority to the law and the requirement that any intervention by public authorities in the sphere of private activities of any person must have a legal basis is - in line with prominent constitutional traditions of the Member States-the nucleus of the rule of law of the Union. ${ }^{87}$ Another typical formal aspect of the rule of law, which can also be found in Union law, is the principle on the hierarchical relationship of norms ${ }^{88}$ which helps the structuring of the legal order.

Article 19 paragraph 1, second sentence TEU manifests, however, that the Union law contains also material aspects of the rule of law. The Union's public authority must be exercised by respecting supra-positive elements of justice ('the law'). ${ }^{89}$ This notion of the 'law' itself as mentioned in Article 19 paragraph 1, second sentence TEU served in the jurisprudence as the starting point for the developing of the Union rule of law as a general principle of law. Yet, this judicial concept of the rule of law is somehow restricted. It refers, due to the systematic place of Article 19 TEU within the Treaty, mainly to the role of the judicial branch in the constitutional system of the

\footnotetext{
${ }^{85}$ See Article 2 lit a) of the proposed regulation of the European Parliament and of the Council on the protection of the Union's budget in case of generalised deficiencies as regards the rule of law in the Member States, COM (2018) 324 final defining the rule of law as 'the Union value enshrined in Article 2 of the Treaty on European Union which includes the principles of legality, implying a transparent, accountable, democratic and pluralistic process for enacting laws; legal certainty; prohibition of arbitrariness of the executive powers; effective judicial protection by independent courts, including of fundamental rights; separation of powers and equality before the law'.

${ }^{86}$ See CJEU, Schrems, supra note 9, para. 60.

${ }^{87}$ CJEU, Case C-496/99 P Commission v. CAS Succhi di Frutta, ECLI:EU:C:2004:236, para. 63. See also CJEU, Joined Cases C-46/87 and 227/88 Hoechst v. Commission, ECLI:EU:C:1989:337, para. 19. But see Kochenov (2015), pp. 81 et seq.

${ }^{88}$ See CFI, Case T-51/89 Tetra Pak v. Commission, ECLI:EU:T:1990:41, para. 25. See Merli (2016), p. 37.

${ }^{89}$ See Rodríguez Iglesias (1996), pp. 125, 128.
} 
Union. ${ }^{90}$ This becomes particularly clear when the Court emphasises the relevance of judicial independence to the Union rule of law. ${ }^{91}$

First of all, the Community of law defines itself in view of the obligation of comprehensive and effective legal protection. ${ }^{92}$ The CJEU's major reference point for the development of the rule of law was therefore for a long time Article 6 ECHR. Further elements of the rule of law, as emphasised by the Court, such as the right to a fair trial and independent courts, which ensure the respect for rules and rights established by Union law, ${ }^{93}$ and even the principle of separation of powers ${ }^{94}$ are also interpreted to serve legal protection before the European Courts.

To be sure, one can derive from the case law further propositions on legal principles such as fundamental rights which are inseparably linked to a material perception of the rule of law. ${ }^{95}$ Without doubt, also the principles of legal certainty and the protection of legitimate expectations ${ }^{96}$ as well as the principle of proportionality pertain to the material concept of 'law', as enshrined in Article 19 TEU, which guarantees 'protection against arbitrary and disproportionate intervention'. ${ }^{97}$ The Court of Justice has, however, always placed these material principles in the context of the legal protection in the Union. It regards the respect for these principles as a requirement for the legality of acts "which it is for the Court to review in the framework of the complete system of legal remedies established by the Treaty'. ${ }^{98}$ The Court has repeatedly pointed out that the material elements of the rule of law must integrate themselves into the system of legal protection in the Union. ${ }^{99}$

\footnotetext{
${ }^{90}$ E.g. CFI, Case T-411/06 Sogelma v. AER, ECLI:EU:T:2008:419, para. 37. See also Rodríguez Iglesias (1996), p. 125; Lenaerts (2007), p. 1625.

${ }^{91}$ See CJEU, Case C-619/18 Commission v. Poland, ECLI:EU:C:2018:1021, paras. 41 et seq.; Commission v. Poland, supra note 52, paras. 21 et seq. See von Danwitz (2016), p. 155.

${ }^{92}$ This principle is specified in: CJEU, Les Verts, supra note 9, para. 23. With respect to Community actions and Member States, see respectively CJEU, Case C-222/84 Johnston v. Chief Constable of the Royal Ulster Constabulary, ECLI:EU:C:1986:206, paras. 18 et seq.; Kadi, supra note 9, paras. 281, 316. See von Bogdandy (2017), p. 497 who perceives judicial control as the core of the 'Rechtsidee' (i.e. legal idea) of the Union.

${ }^{93}$ CJEU, Joined Cases C-174/98 P and C-189/98 P Netherlands and Van der Wal v. Commission, ECLI:EU:C:2000:1, para. 17. See Badó and Bóka (2016), p. 46.

${ }^{94}$ CJEU, Poltorak, supra note 59, paras. 44-45; Case C-477/16 Kovalkovas, ECLI:EU:C:2016:861, paras. 43-44.

${ }^{95} \mathrm{CJEU}$, Kadi, supra note 9, para. 285.

${ }^{96} \mathrm{CJEU}$, Case C-10/69 Portelange v. Smith Corona Marchant International, ECLI:EU:C:1969:36, para. 15/16; Joined Cases 205 to 215/82 Deutsche Milchkontor GmbH v. Germany, ECLI:EU: C:1983:233, paras. 27 et seq. See Gamper (2016), p. 80.

${ }^{97}$ This norm is understood to be a general principle of (EU) law, see CJEU, Case C-4/73 Nold KG v. Commission, ECLI:EU:C:1974:51, para. 13; Hoechst v. Commission, supra note 87, para. 19. See Huber (2016), p. 98.

${ }^{98} \mathrm{CJEU}$, Kadi, supra note 9, para. 285.

${ }^{99} \mathrm{CJEU}$, Accession of the EU to the ECHR II, supra note 12, para. 177. See Jaeger (2018), pp. 626 et seq.
} 
The motive of the Court's quest for legal protection is not only a demand for the safeguarding of individual rights, but also a demand for the full and effective application of Union law in the Member States. The legal requirement that all courts and tribunals in the Union have 'to ensure the full application of EU law in all Member States and judicial protection of the rights of individuals under that law', is, in the words of the CJEU, an 'expression (of) the value of the rule of law affirmed in Article 2 TEU'. ${ }^{100}$ By this token, the rule of law may be regarded also as an instrument safeguarding the autonomy of the Union legal order and to protect it against internal and external challenges. ${ }^{101}$

\section{Essence of the Union Rule of Law}

What remains is the insight that the rule of law constitutes a 'conceptual puzzle' in the Union legal order since there exist different conceptions of its significance and its content beyond its basic meaning that any form of public power must be subordinated to some kind of primary, unchangeable norms. This principle cannot be defined conclusively and it may evolve over time.

At the same time, from the point of view of Union law, it is indispensable to determine the rule of law more precisely; not only is it referred to in black-letter treaty law (Article 2 TEU), but understood by Union courts as a constitutional metaprinciple that provides a justification for review proceedings and informs other constitutional norms. ${ }^{102}$ Moreover, its respect, or not, entails legal consequences. Inasmuch as the rule of law constitutes a general principle of law, it is necessary to draw on both the pertinent case law of the European courts as well as the common constitutional traditions of the Member States (Article 6 paragraph 3 TEU).

Due to the above-explained common European constitutional tradition it is well established that the European rule of law does not only have a formal, but also a material side and includes substantive claims for justice and the prohibition of arbitrariness. At the same time, the vehement warning that the rule of law might be overstretched shows that the containment of public authority by institutional arrangements is still one of the core concerns of the rule of law. This also corresponds to the jurisprudence of the European courts which underscores the procedural safeguarding of justice. Among these principles figure the principle of hierarchy of norms and of legality, i.e. the binding of the legislator to the constitution and of the administrative and judicial powers to the law, the transparency and perceptibility of

\footnotetext{
${ }^{100} \mathrm{CJEU}$, LM, supra note 52, para. 50. Similar CJEU, Case C-64/16 Associação Sindical dos Juízes Portugueses v. Tribunal de Contas, ECLI:EU:C:2018:117, para. 32; Case C-284/16 Achmea, ECLI: EU:C:2018:158, para. 36.

${ }^{101}$ This does, however, not imply that in the case law of the CJEU the rule of law is 'pre-empted' by considerations of Union autonomy as Kochenov (2015), pp. 78, 93 et seq. suggests.

${ }^{102}$ Pech (2010), pp. 376 et seq.; Holterhus (2017), p. 460; Barnett (2018), p. 34.
} 
norms. In addition, also the principles of separation of powers and of effective legal protection by independent courts are counted among the formal institutional guarantees of the rule of law. As far as the implementation and understanding of these principles in a more detailed fashion are concerned, there exist significant differences among the Member States' constitutions.

In view of the strong tradition of a formal approach to the rule of law in Europe, consensus at the Union level might be achieved on the fact that the rule of law comprises not only strictly formal standards but also material criteria of justice that are related to the juridical shaping of decision-making processes. Characteristic examples are principles such as legal certainty, protection of legitimate expectations and proportionality.

All these subprinciples of the rule of law shall ensure that any public power is exercised in a non-arbitrary and legitimate way. To this end, they may not only be understood as objective norms but also ensure the protection of individual rights. As Article 52 paragraph 1 of the FRC makes clear in relation to the principle of proportionality, these material standards are intrinsically linked to fundamental rights. ${ }^{103}$ To the extent that a restriction of fundamental rights is effected without a legal basis within the meaning of Article 52 paragraph 1, first sentence FRC, ${ }^{104}$ that this restriction is disproportionate given certain common interests, that it does not satisfy the claims of legal certainty or that it does not provide for an appropriate legal protection mechanism, one may not only assume that human rights have been violated but also that a violation of the rule of law has occurred, which may be challenged by any individual before a Union court of law. ${ }^{105}$

Fundamental rights and rule of law principles are, in the Union constitutional system, mutually dependent and reinforce each other. ${ }^{106}$ The Union rule of law aims at protecting individual fundamental rights and, conversely, fundamental rights are a material prerequisite of such a rule of law. At most, one can say that the guarantee of the institution of fundamental rights is an essential component of a Union under the rule of law. Individual fundamental rights are, however, not necessarily part of the rule of law, ${ }^{107}$ as is also made clear by Article 2 TEU which conceives the rule of law and fundamental rights as different principles. Moreover, there is no constitutional law surplus value in qualifying single human rights additionally as an element of the rule of law as they are sufficiently assured by the Article 6 TEU and the European Charter of Fundamental Rights which is legally binding.

\footnotetext{
${ }^{103}$ Venice Commission for Democracy through Law, Study No. 711/2013, supra note 83, para. 31. ${ }^{104}$ CJEU, Hoechst v. Commission, supra note 87, para. 19.

${ }^{105}$ CJEU, Kadi, supra note 9, para. 316; Commission v. Poland, supra note 52, para. 21; LM, supra note 52 , para. 48 et seq.

${ }^{106}$ This applies in particular to the principle of effective judicial protection which forms part of the rule of law but finds also expression in Article 47 FRC, see Konstantinides (2017), p. 83.

${ }^{107}$ Lenaerts (2017a), p. 641.
} 


\section{References}

Badó A, Bóka J (2016) Access to justice and judicial independence. In: Schroeder W (ed) Strengthening the rule of law in Europe. Hart, Oxford, pp 46-60

Baquero Cruz J (2008) The legacy of the Maastricht-Urteil and the pluralist movement. Eur Law J 14:389-422

Barnett G (2018) Reflections on what the rule of law means and its significance at EU level. In: Hatje A, Tichý L (eds) Liability of member states for the violation of fundamental values of the European Union. Nomos Verlagsgesellschaft mbH \& Co. KG, Baden-Baden, pp 23-38. EuR Beiheft 1

Bengoetxea J (1993) The legal reasoning of the European court of justice: towards a European jurisprudence. Clarendon Press, Oxford

Bingham T (2010) The rule of law. Allen Lane, London

Calliess C (2004) Europa als Wertegemeinschaft - Integration und Identität durch europäisches Verfassungsrecht? Juristenzeitung 59:1033-1084

Calliess C (2011) EUV Art 2. In: Calliess C, Ruffert M (eds) EUV/AEUV: Kommentar, 4th edn. CH Beck, Munich

Claes M, Bonelli M (2016) The rule of law and the constitutionalisation of the European Union. In: Schroeder W (ed) Strengthening the rule of law in Europe. Hart, Oxford, pp 265-289

Classen CD (2013) Nationales Verfassungsrecht in der Europäischen Union: eine integrierte Darstellung der 27 Verfassungsordnungen. Nomos, Baden-Baden

Crabit E, Bael N (2016) The EU rule of law framework. In: Schroeder W (ed) Strengthening the rule of law in Europe. Hart, Oxford, pp 197-206

Craig PP (1997) Formal and substantive conceptions of the rule of law: an analytical framework. Public Law 467:1-15

Cremona M (2005) EU enlargement: solidarity and conditionality. Eur Law Rev 30:3-22

Cruz Villalón P (2007) Vergleich. In: von Bogdandy A, Huber PM, Cruz Villalón P (eds) Handbuch Ius Publicum Europaeum, Band I: Grundlagen und Grundzüge staatlichen Verfassungsrechts. CF Müller, Heidelberg, pp 729-778, § 13

Dicey AV (1961) Introduction to the study of the law of the constitution, 10th edn. Palgrave Macmillan, London

Dworkin R (1985) A matter of principle. Oxford University Press, Oxford

Fuchs M (2018) Die Vermessung der Rechtsstaatlichkeit - Die 'Rule of Law Checklist' der Venedig-Kommission des Europarates. EuGRZ 45:237-243

Fuß EW (1968) Die Europäischen Gemeinschaften und der Rechtsstaatsgedanke. UGA, Heule

Gamper A (2016) Legal certainty. In: Schroeder W (ed) Strengthening the rule of law in Europe. Hart, Oxford, pp 80-97

Hallstein W (1969) Der unvollendete Bundesstaat: europäische Erfahrungen und Erkenntnisse. Econ-Verlag, Düsseldorf

Hallstein W (1979) Die EWG als Schritt zur Europäischen Einheit. In: Oppermann T (ed) Walter Hallstein — Europäische Reden. Deutsche Verlags-Anstalt, Stuttgart, pp 103-112

Heuschling L (2002) État de Droit: Rechtsstaat: rule of law. Dalloz, Paris

Hilf M, Schorkopf F (2015) EUV Art 2. In: Grabitz E, Hilf M, Nettesheim M (eds) Das Recht der Europäischen Union: EUV/AEUV, 57th edn. CH Beck, Munich

Hillion C (2016) Overseeing the rule of law in the EU: legal mandate and means. In: Closa C, Kochenev D (eds) Reinforcing rule of law oversight in the EU. Cambridge University Press, Cambridge, pp 59-81

Holterhus T (2017) The history of the rule of law. Max Planck Yearb United Nations Law 21:430-466

Huber PM (2016) The principle of proportionality. In: Schroeder W (ed) Strengthening the rule of law in Europe. Hart, Oxford, pp 98-112

Jaeger T (2018) Gerichtsorganisation und EU-Recht: Eine Standortbestimmung. Europarecht 53:611-652 
Kochenov D (2013) The EU in its most serious crisis ever (and that's not the Euro crisis). http:// verfassungsblog.de/en/the-eu-in-its-most-serious-crisis-ever-and-thats-not-the-euro-crisis-2 . Accessed 15 Mar 2019

Kochenov D (2015) EU law without the rule of law: is the veneration of autonomy worth it? Yearb Eur Law 34:74-96

Konstantinides T (2017) The rule of law in the European Union - the internal dimension. Hart, Oxford

Krygier M (2012) Rule of law. In: Rosenfeld M, Sajó A (eds) The Oxford handbook of comparative constitutional law. Oxford University Press, Oxford, pp 233-249

Kunig P (1986) Das Rechtsstaatsprinzip: Überlegungen zu seiner Bedeutung für das Verfassungsrecht der Bundesrepublik Deutschland. Mohr Siebeck, Tübingen

Lenaerts K (1990) Constitutionalism and many faces of federalism. Am J Comp Law 38:205-263

Lenaerts K (2007) The rule of law and the coherence of the judicial system of the European Union. Common Market Law Rev 44:1625-1659

Lenaerts K (2017a) Die Werte der Europäischen Union in der Rechtsprechung des Gerichtshofs der Europäischen Union: eine Annäherung. EuGRZ 21:639-642

Lenaerts K (2017b) La vie après l'avis: exploring the principle of mutual (yet not blind) trust. Common Market Law Rev 54:805-840

Loughlin M (2010) Foundations of public law. Oxford University Press, Oxford

Luhmann N (1987) Soziale Systeme: Grundriß einer allgemeinen Theorie. Suhrkamp, Frankfurt am Main

MacCormick N (1995) The Maastricht-Urteil: sovereignity now. Eur Law J 1:259-266

Magen A (2016) Cracks in the foundation: understanding the great rule of law debate in the EU. J Common Market Stud 54:1050-1061

Mancini GF (1989) The making of a constitution for Europe. Common Market Law Rev 26:595-614

Mangiameli S (2013) Article 2: the homogeneity clause. In: Blanke H-J, Mangiameli S (eds) The treaty on European Union (TEU). A commentary. Springer, Heidelberg, pp 109-155

Merli F (2016) Principle of legality and the hierarchy of norms. In: Schroeder W (ed) Strengthening the rule of law in Europe. Hart, Oxford, pp 37-45

Möstl M (2010) Preconditions and limits of mutual recognition. Common Market Law Rev 47:405-436

Ohler C (2015) EUV Art 49. In: Grabitz E, Hilf M, Nettesheim M (eds) Das Recht der Europäischen Union: EUV/AEUV, 57th edn. CH Beck, Munich

Pech L (2010) 'A union founded on the rule of law': meaning and reality of the rule of law as a constitutional principle of EU law. Eur Const Law Rev 6:359-396

Pernice I (1995) Carl Schmitt, Rudolf Smend und die europäische Integration. Archiv des öffentlichen Rechts 120:100-120

Raz J (1977) The rule of law and its virtue. Law Q Rev 93:195-211

Rodríguez Iglesias GC (1996) Zur 'Verfassung' der Europäischen Gemeinschaft. EuGRZ 23:125-131

Scharpf FW (1985) Die Politikverflechtungsfalle: Europäische Integration und deutscher Föderalismus im Vergleich. Politische Vierteljahresschrift 26:323-356

Scheppele KL (2015) Understanding Hungary's constitutional revolution. In: von Bogdandy A, Sonnevend P (eds) Constitutional crisis in the European constitutional area: theory, law and politics in Hungary and Romania. Hart, Oxford, pp 111-124

Schmidt-Aßmann E (2004) Der Rechtsstaat. In: Isensee J, Kirchhof P (eds) Handbuch des Staatsrechts der Republik Deutschland, Band II: Verfassungsstaat. C.F. Müller, Heidelberg, pp 541-612, § 26

Schmitt C (1985) Politische Theologie - Vier Kapitel zur Lehre von der Souveränität, 4th edn. Duncker \& Humblot, reprint, Berlin

Schmitt C (2008) Constitutional theory. Duke University Press, Durham 
Schroeder W (2002) Das Gemeinschaftsrechtssystem: eine Untersuchung $\mathrm{zu}$ den rechtsdogmatischen, rechtstheoretischen und verfassungsrechtlichen Grundlagen des Systemdenkens im Europäischen Gemeinschaftsrecht. Mohr Siebeck, Tübingen

Sobotta K (1997) Das Prinzip Rechtsstaat: Verfassungs- und verwaltungsrechtliche Aspekte. Mohr Siebeck, Tübingen

Tridimas T (2013) The general principles of EU law, 3rd edn. Oxford University Press, Oxford von Bogdandy A (2009) Founding principles. In: von Bogdandy A, Bast J (eds) Principles of European constitutional law, 2nd edn. Hart, Portland, pp 11-54

von Bogdandy A (2017) Jenseits der Rechtsgemeinschaft - Begriffsarbeit in der europäischen Sinnund Rechtsstaatlichkeitskrise. EuR 52:487-511

von Bogdandy A, Ioannidis M (2014) Systemic deficiency in the rule of law: what it is, what has been done, what can be done. Common Market Law Rev 51:59-96

von Bogdandy A et al (2012) Reverse Solange - protecting the essence of fundamental rights against member states. Common Market Law Rev 49:489-520

von Bogdandy A et al (2018) A potential constitutional moment for the European rule of law - the importance of red lines. Common Market Law Rev 55:983-996

von Danwitz T (2016) The rule of law in the recent jurisprudence of the ECJ. In: Schroeder W

(ed) Strengthening the rule of law in Europe. Hart, Oxford, pp 155-169

von Simson W (1982) Die Deutschen und ihr Rechtsstaat. Der Staat 21:97-112

Waldron J (2008) The concept and the rule of law. Georgia Law Rev 43:1-61

Weiler JHH (1981) The community system: the dual character of supranationalism. Yearb Eur Law 1:267-306

Wennerström EO (2007) The rule of law and the European Union. Lustu Forlag, Uppsala

Werner Schroeder is Full Professor at the Department of European Law and Public International Law, University of Innsbruck, Austria.

Open Access This chapter is licensed under the terms of the Creative Commons Attribution 4.0 International License (http://creativecommons.org/licenses/by/4.0/), which permits use, sharing, adaptation, distribution and reproduction in any medium or format, as long as you give appropriate credit to the original author(s) and the source, provide a link to the Creative Commons license and indicate if changes were made.

The images or other third party material in this chapter are included in the chapter's Creative Commons license, unless indicated otherwise in a credit line to the material. If material is not included in the chapter's Creative Commons license and your intended use is not permitted by statutory regulation or exceeds the permitted use, you will need to obtain permission directly from the copyright holder. 